\title{
Prospects and technology of cultivation of organic vegetable production on open ground in southern Russia conditions
}

\author{
Anzor Ezov ${ }^{1, *}$, Zalim-Geri Shibzukhov ${ }^{1}$, Beslan Beslaneev $^{2}$, Zalina Shibzukhova ${ }^{1}$, and \\ Martin Khantsev ${ }^{1}$ \\ ${ }^{1}$ Kabardino-Balkarian State University, st. Chernyshevsky, 173, 360004 Nalchik, Kabardino- \\ Balkarian Republic, Russia \\ ${ }^{2}$ Kabardino-Balkarian State Agrarian University named after V.M. Kokov, st. Ave. Lenina, 1B, \\ 360030 Nalchik, Kabardino-Balkarian Republic, Russia
}

\begin{abstract}
To receive a high-quality competitive and environmentally friendly product, you need a well-thought-out agricultural technology, high level of biosecurity and spatial isolation. To develop an effective technology for growing environmentally friendly new potatoes, in the soil and climatic conditions of the high-altitude zone of Kabardino-Balkaria, scientific work was carried out, taking into account the achievements of modern agriculture. In the conditions of the mountain zone, nature has created a clean phytosanitary zone, in which you can get high-quality, environmentally friendly products without increasing their cost. The production process in this case will exclude the control of diseases and pests that in this zone will not exceed the economic threshold of harmfulness. In potato seed production, the initial stage was the use of improved material for growing a regenerating plant from the meristem, propagated in sterile, laboratory conditions for further cloning. With such seed material that is initially free of pathogens, it is much easier to get organic products. According to various estimates, the cost of producing environmentally friendly products in agriculture is $2.5-3$ times higher than the cost of traditional production, and as a result, the cost of products increases. The analysis of economic efficiency showed that the increase in net income depends on the received potato yield and the sale price of new potatoes.
\end{abstract}

\section{Introduction}

Worldwide, the introduction of intensive technologies in the production of vegetables with purpose to increase production volume means increasing of the chemical load. Use of pesticides for controlling pests and diseases significantly increasing, rates of application of mineral fertilizers are also increasing. The use of pesticides for pest and disease control is significantly increased, and the norms for applying mineral fertilizers are increased, which significantly reduces the environmental performance of vegetable products $[13,14]$.

*Corresponding author: ezaov@rambler.ru 
In this regard, there is a need for environmentally friendly products. Consumption of it will help to cleanse human organism from the harmful effects of contaminated food, restore normal functions and increase life expectancy. After all, there is nothing more voluble than health. If a person feels himself well, he can productively work for the benefit of the family and the society [1].

Agricultural producers need to switch to ecological farming. This is especially true for the technologies of producing vegetables, fruits, dairy products. That is, the products responsible for our health. They should, first of all, meet the following requirements: contain the necessary amount of vitamins; do not cause allergies; be useful for children of any age; have a natural taste and aroma. Scientists have proved that if you eat organic vegetables grown in compliance with environmental standards, the human body can improve by $30-40 \%$ [2].

Innovative technology of growing organic vegetable products in conditions of limited spatial isolation of the mountain zone involves: conducting research work on the development of technology of growing environmentally friendly products in a clean phytosanitary zone; for the needs of the people, who are in group of risk.

Research problems are:

- to develop a scientific system of crop rotation to maintain and improve soil fertility in the conditions of organic farming;

- to develop a technology that excludes the use of mineral fertilizers and chemicals in plants production;

- develop a system of disease and pest control using biological methods;

- involvement of ecologically clean mountain areas in the production of higher quality products suitable for long-term storage and processing for children's and dietary food.

In isolation, with high level agricultural technology, high level of biosecurity measures, high-quality competitive environmentally friendly product can be grown. It is necessary to take into account the whole complex of laws of agriculture and crop production when introducing a special organic vegetable crop rotation [3].

The first step in this direction was the research on the cultivation of environmentally friendly new potatoes, in soil and climatic conditions of the mountainous zone of Kabardino-Balkaria. Thus, with grows of altitude above sea level number and activity of insects-vectors reduces, resulting in weakened background infecting load, it is in conjunction with the developed scientifically sound crop rotation completely eliminates the use of chemical crop protection products.

Also, innovation of technology of organic products is that for planting was used new generation of seed material guaranteed (100\%) pathogens free, grown under innovative technologies by LLC “Zolsky kartofel”, which has number of advantages compared to seed material produced by traditional technologies.

The modern policy of agricultural production implies the necessity of switching to ecological agriculture. This is especially true for the technology of growing vegetables, fruits, dairy products. That is the products responsible for our health. They should, first of all, meet the following requirements: contain a large amount of vitamins; do not cause allergies; be useful for children of any age; have a natural taste and aroma; and the use of food would contribute in improvement of the human body, surge of energy, activation of life, increase immunity. Scientists have proved that if you eat organic vegetables grown in compliance with environmental standards, the human body can improve by $30-40 \%$ [2].

The experience of countries with advanced technology shows that the market is stimulated by the creation of new approaches to improving the environmental friendliness of agricultural production, its economic efficiency and demand by the people. In our country, where the importance of intensive factors in the development of the industry has dramatically increased recently, this issue is very relevant. This was also noted by President 
Vladimir Putin in his report on the prospects for the development of agriculture in the near future, which should be given special attention. President of Russian Federation Vladimir Putin in his address to the Federal Assembly demanded to create a Russian "green brand". In his speech, he said: "Our natural advantage (I think that everyone will agree with this) is huge natural opportunities, they need to be used to increase the production of environmentally friendly products. I instruct the government to create a protected brand of domestic clean, "green" products, it must confirm that its production uses only safe technologies for human health, to serve as a guarantee of high quality in the domestic and foreign markets. On foreign market everything will fly out, I assure you, there is no clean production abroad is left" [5].

Production of organic products is possible only due to intensification, providing for the introduction of more efficient varieties, advanced cultivation technologies [6].

Scientific and practical interest is the development and implementation of science-based technologies for the cultivation of organic vegetable crops of domestic varieties in conditions favorable to phytosanitary mountain zone, which provides the most complete realization of the potential of culture.

\section{Methods and conditions of the study}

The research was carried out in 2017 - 2019 years on the lands of Zalukodes village, in a special vegetable organic crop rotation with alternation of crops:

Special vegetable organic crop rotation:

1. Winter barley with alfalfa sowing;

2. Alfalfa - 1st year;

3. Alfalfa - 2-year;

4. Medium-ripe cabbage;

5. Table beet (oil radish with sealing in the spring);

7. Potato;

6. Bean.

For the experiments we used domestic varieties of potatoes for table purposes. Sprouted potato tubers were planted in the pre-heated to $8^{\circ} \mathrm{C}$ soil on depth of $10 \mathrm{~cm}$. Architectonics landing $(60+80) / 20) \times 30 \mathrm{~cm}$. The location of the direction of rows in relation to the cardinal points, North to South, which will improve the illumination of plants in the row spacing, an increase in the mass of foliage, the area of assimilation surface of leaves and net productivity of photosynthesis, the formation of additional lateral shoots.

After harvesting of the table beet we sowed radish as a green manure crop. In the spring, before cutting the ridges, compost was made at the rate of $10 \mathrm{t} / \mathrm{ha}$ within the boundaries of the tape for planting potatoes. Also, the green manure was sealed with disc harrows to a depth of $5-6 \mathrm{~cm}$. Whole complex of potato planting care was aimed at combating weeds and consisted in the following: two row-to-row treatments with simultaneous harrowing. Post-emergence care two row-to-row treatments to kill weeds and loosen the soil. The depth of tillage did not exceed $6 \mathrm{~cm}$. The soil before planting was treated with an aqueous solution of HB-101 at the rate of: - $100 \mathrm{ml} \mathrm{HB}-101$ per 2000 liters of water per area of 2 ha.

\section{Researches results}

The data analysis of the harvest of early potatoes of different varieties showed that climatic conditions of the mountain zone are quite suitable for growing potato tubers with a commercial yield of $20.5 \mathrm{t} / \mathrm{ha}$. In terms of pure phytosanitary zone of the KBR (Kabardino- 
Balkarian Republic), the studied varieties of early potatoes had the highest yield in the range of $18-21$ t/ha (table 1$)$.

Table 1. Crop yield of early-ripening potato varieties in conditions of mountainous zone of KBR, $t$ / ha, 2019 year

\begin{tabular}{|c|c|c|c|c|c|}
\hline \multirow{2}{*}{$\begin{array}{l}\text { Soil and climatic } \\
\text { conditions }\end{array}$} & \multirow[t]{2}{*}{ Variety } & \multicolumn{3}{|c|}{ Grade of Replications, $t / h a$} & \multirow[t]{2}{*}{ Avarage, $\mathrm{t} / \mathrm{ha}$} \\
\hline & & 1 & 2 & 3 & \\
\hline \multirow{5}{*}{ Early consumption } & Goryanka & 18.3 & 18.7 & 17.8 & 18.3 \\
\hline & Zhukovsky raniy & 21.4 & 20.1 & 22.8 & 21.4 \\
\hline & Udacha & 21.7 & 17.7 & 19.2 & 19.5 \\
\hline & Utenok & 19.2 & 20.4 & 18.5 & 19.9 \\
\hline & Nalchikskiy & 19.4 & 20.8 & 20.1 & 20.1 \\
\hline \multirow[t]{5}{*}{ Mature tubers } & Goryanka & 24.5 & 21.3 & 21.7 & 22.5 \\
\hline & Zhukovsky raniy & 25.8 & 28.6 & 26.1 & 26.8 \\
\hline & Udacha & 22.4 & 19.8 & 23.4 & 21.9 \\
\hline & Utenok & 23.1 & 25.6 & 27.8 & 25.0 \\
\hline & Nalchikskiy & 28.8 & 29.3 & 0.9 & 28.7 \\
\hline $\begin{array}{l}\text { Least significant } \\
\text { difference } 05, \mathrm{t} / \mathrm{ha}\end{array}$ & & 0.7 & 0.7 & 0.9 & \\
\hline
\end{tabular}

High yield of potato tubers was received due strict following of this technology of growing early-ripening varieties in the conditions of the mountain zone. This, first of all, concerns the maintenance of a favorable background of mineral nutrition by composting and planting green manure in the soil, strict observance of measures for the care of plantings during the growing season.

Potato plants have formed a yield of $25 \mathrm{t} / \mathrm{ha}$, which is a satisfactory result for the mountain zone, and taking to consideration the technology of organic farming, the productivity of potatoes is high.

The next stage of our research was sorting potatoes to determine the number of commercial tubers (table 2).

Table 2. Crop yield of marketable organic potatoes of different varieties in conditions of mountainous zone of KBR, 2019 year

\begin{tabular}{|l|l|c|c|c|c|c|}
\hline \multirow{3}{*}{$\begin{array}{c}\text { Soil and climatic } \\
\text { conditions }\end{array}$} & \multicolumn{1}{|c|}{ Variety } & \multicolumn{3}{|c|}{$\begin{array}{c}\text { Grade of } \\
\text { Replications, } \mathrm{t} / \mathrm{ha}\end{array}$} & \multirow{2}{*}{$\begin{array}{c}\text { Avarag } \\
\mathrm{e}\end{array}$} & $\begin{array}{c}\text { Marketabil } \\
\text { ity } \%\end{array}$ \\
\cline { 2 - 7 } & & 1 & 2 & 3 & & \\
\hline \multirow{5}{*}{ Mountain zone } & Goryanka & 23.8 & 20.7 & 22.7 & 21.8 & 97 \\
\cline { 2 - 7 } & $\begin{array}{l}\text { Zhukovsky } \\
\text { raniy }\end{array}$ & 25.3 & 28.0 & 26.1 & 26.3 & 98 \\
\cline { 2 - 7 } & Udacha & 22.0 & 19.2 & 22.7 & 21.2 & 97 \\
\cline { 2 - 7 } & Utenok & 23.1 & 25.6 & 26.4 & 24.5 & 98 \\
\cline { 2 - 6 } & Nalchikskiy & 28.3 & 28.8 & 27.0 & 28.1 & 98 \\
\hline $\begin{array}{l}\text { Least significant } \\
\text { difference 05, t/ha, } \\
\text { steppe zone }\end{array}$ & 3.6 & 3.6 & 2.8 & 4.8 & 0.7 \\
\hline
\end{tabular}

Thus, obtaining a high commodity yield of potatoes in the studied varieties of food new potatoes and mature tubers shows that early-ripening varieties of potatoes in the conditions of the mountain zone showed high environmental plasticity. All tested varieties of domestic selection can be attributed to varieties of intensive type.

When growing organic potatoes, the main goal is to obtain environmentally friendly tubers with high yields and nutritional value. The possibility of using this product in 
children's nutrition, healthy nutrition, for pregnant women, i.e. for those who are more susceptible to the quality of the food [7].

According to the conducted studies, it was possible to reveal that the studied varieties have different biochemical composition and differ in taste.

According to the starch content, which is the leading indicator of the quality of potato tubers, studies have shown that early varieties have high indicators: Utenok - 14.2\%, which surpassed the other varieties: Zhukovsky raniy by $0.9 \%$, Goryanka by $1.6 \%$.

And only the average early variety Nalchiksky was at the level of the Utenok variety $14.1 \%$. In early-ripening varieties of potatoes, there is less starch than in medium-early ones, which is a varietal feature.

In the soil and climatic conditions of the mountain zone in the studied varieties of early ripening, its average content was 16\% (table 3 ).

Table 3. Biochemical composition and taste qualities of ecologically clean tubers of new food potatoes, 2019 year

\begin{tabular}{|l|c|c|c|c|c|c|c|}
\hline \multicolumn{1}{|c|}{ Variety } & $\begin{array}{c}\text { Total } \\
\text { moisture, } \\
\%\end{array}$ & $\begin{array}{c}\text { Dry } \\
\text { matter, } \\
\%\end{array}$ & $\begin{array}{c}\text { Starch, } \\
\%\end{array}$ & $\begin{array}{c}\text { Protein, } \\
\%\end{array}$ & $\begin{array}{c}\text { Sugar, } \\
\%\end{array}$ & $\begin{array}{c}\text { Vitamin } \\
\mathrm{C}, \mathrm{mg} \\
\%\end{array}$ & $\begin{array}{c}\text { Taste, } \\
\text { points }\end{array}$ \\
\hline Goryanka & 81.8 & 18.2 & 12.7 & 2.84 & 0.43 & 15.2 & 4.5 \\
\hline $\begin{array}{l}\text { Zhukovsky } \\
\text { raniy }\end{array}$ & 81.3 & 18.7 & 13.3 & 2.93 & 0.48 & 14.8 & 4.8 \\
\hline Udacha & 81.3 & 18.7 & 13.8 & 3.03 & 0.41 & 14.9 & 4.1 \\
\hline Utenok & 81.2 & 18.8 & 14.2 & 3.11 & 0.42 & 13.2 & 4.0 \\
\hline Nalchikskiy & 82.1 & 17.9 & 14.1 & 3.08 & 0.45 & 14.5 & 4.3 \\
\hline
\end{tabular}

It should be noted that when comparing the taste characteristics of tubers obtained in the conditions of organic farming in the mountain zone and the same varieties in the conditions of the foothill zone with conventional technology, all tasters noted the superiority of organic potatoes.

Zhukovsky early and Goryanka varieties are distinguished with high taste indices. Other varieties showed results at the level of $4.1-4.5$ points.

On the basis of the system-reproduction approach, the efficiency of agricultural production is determined on the basis of increasing the number of production products while reducing labor costs for its production. After evaluating the results of experimental tests, the selection of crops and varieties of organic products is carried out, with the cultivation of which it is possible to achieve the highest productivity in combination with the maximum level of profitability of production [8].

Comprehensive assessment of organic products in industrial production is carried out on the basis of economic analysis using GIS technologies.

The economic assessment was carried out on the basis of the following parametric data of the studied crops: crop yield, gross harvest, the cost of gross production at purchase prices, the total cost per $1 \mathrm{ha}$, net income, profitability level.

In the production of organic products, most often there is an increase in prices, due to the increase in labor intensity (the share of manual labor increases), the cost of preparing and applying of compost. At the same time, it is not always possible to improve the external, qualitative indicators of the resulting eco-products.

In the conditions of the mountain zone, nature has created a clean phytosanitary zone, in which one can get high-quality, environmentally friendly products without increasing its cost. The production process in this case will exclude the fight against diseases and pests, which in this zone will not exceed the economic threshold of harmfulness [9].

In case with potatoes, it should be noted that the seed material was obtained in the same phytosanitary conditions of the mountain zone. And in potato seed production, the initial 
stage was the use of improved material for growing a regenerate plant from the meristem, propagated in sterile, laboratory conditions for further cloning. With such seed material, initially free from pathogens, it is much easier to obtain organic products. But in our conditions is a big plus of using high quality seed, the highest reproduction at high altitudes is reduced or absent pests and disease vectors.

The cost of production of environmentally safe products in agriculture is 3 times higher than the cost of traditional production and as a result, its cost is much higher - there is a growing demand for added value of the product: increased quality, naturalness, enrichment.

The analysis of the results showed that the increase in net income is due to the high yield of potatoes and the high wholesale price of new potatoes. It should be noted that wholesale prices for the environmental friendliness of the resulting products in the calculations did not increase compared to products obtained by conventional technology. Although such organic production is $2-3$ times more expensive. The cost of new potatoes of domestic varieties is $40 \%$ lower than ones imported from Egypt, Iran, etc.

For all varieties, high profitability of growing young industrial potatoes was obtained.

Table 4. Economic efficiency of growing early-ripening potato varieties for organic new table potatoes

\begin{tabular}{|l|c|c|c|c|c|}
\hline \multirow{2}{*}{ Indicators } & \multicolumn{5}{|c|}{ Varieties } \\
\cline { 2 - 6 } & Goryanka & $\begin{array}{c}\text { Zhukovsky } \\
\text { raniy }\end{array}$ & Udacha & Utenok & Nalchikskiy \\
\hline Crop yield, t/ha & 18.3 & 21.4 & 19.5 & 19.9 & 20.1 \\
\hline $\begin{array}{l}\text { Direct costs of } \\
\text { growing production, } \\
\text { thousands of rubles }\end{array}$ & 64.8 & 65.3 & 65.2 & 65.5 & 65.9 \\
\hline $\begin{array}{l}\text { Price of 1 ton, } \\
\text { thousands of rubles }\end{array}$ & 15 & 17 & 15 & 15 & 15 \\
\hline $\begin{array}{l}\text { Gross value, } \\
\text { thousands of rubles }\end{array}$ & 274.5 & 363.8 & 292.5 & 298.5 & 301.5 \\
\hline $\begin{array}{l}\text { Net income, } \\
\text { thousands of rubles }\end{array}$ & 209.7 & 298.5 & 227.3 & 233.5 & 235.6 \\
\hline Profitability level, \% & 324 & 457 & 349 & 356 & 358 \\
\hline
\end{tabular}

High profitability of the Zhukovsky early variety (457\%) is noted due to the fact that the wholesale price for this variety is higher and productivity is at a high level. The Zhukovsky early variety has a high conditional net income - 298.5 thousand rubles/ha, which is $133 \%$ more than the Goryanka variety.

Studies have shown that the production of environmentally friendly new potatoes in the highlands is highly profitable production, so it is economically feasible to grow potatoes of early consumption by environmentally safe technology, and primarily domestic varieties in the mountainous zone.

The comparative economic efficiency of growing vegetables in conditions of organic farming and conventional intensive technology (table 5) shows that there is no significant increase in the cost of organic production in the mountainous zone.

Increase of the cost for environmental friendliness on at least $40 \%$ leads to an increase in the gross value of organic potato production by 249.5 thousand rubles, while the crop yield is reduced by $2.5 \mathrm{t} / \mathrm{ha}$.

Net income and profitability increases almost 2 times in the production of organic potatoes compared to conventional technology. The table also shows that medium-ripe cabbage, table beets and beans obtained in compliance with environmental standards of organic farming, even without added value for specificity have high economic indicators. The profitability of production of environmentally friendly cabbage is $378 \%$, which is at 
the level of production by intensive technology in the conditions of the foothill and steppe zone of the KBR.

Table beet, even with a price reduction to 7 thousand rubles per ton had profitability of $414 \%$, which indicates the high profitability of growing this crop.

Table 5. Economic efficiency of cultivation of vegetable crops in crop rotation

\begin{tabular}{|c|c|c|c|c|c|}
\hline \multirow[b]{2}{*}{ Indicators } & \multicolumn{5}{|c|}{ Crop rotation } \\
\hline & $\begin{array}{l}\text { Medium-ripe } \\
\text { cabbage on } \\
\text { organic } \\
\text { farming } \\
\text { technology }\end{array}$ & $\begin{array}{l}\text { Table beet } \\
\text { on organic } \\
\text { farming } \\
\text { technology }\end{array}$ & $\begin{array}{l}\text { Beans on } \\
\text { organic } \\
\text { farming } \\
\text { technology }\end{array}$ & $\begin{array}{l}\text { Potatoes } \\
\text { Nalchikskiy } \\
\text { variety on } \\
\text { intensive } \\
\text { technology }\end{array}$ & $\begin{array}{c}\text { Potatoes } \\
\text { Nalchikskiy } \\
\text { variety on } \\
\text { organic } \\
\text { farming } \\
\text { technology }\end{array}$ \\
\hline Crop yield, t/ha & 34 & 26 & 1.4 & 31.2 & 28.7 \\
\hline $\begin{array}{l}\text { Direct costs of } \\
\text { growing } \\
\text { production, } \\
\text { thousands of } \\
\text { rubles }\end{array}$ & 85.4 & 35.4 & 32.2 & 75.1 & 71.4 \\
\hline $\begin{array}{l}\text { Price of } 1 \text { ton, } \\
\text { thousands of } \\
\text { rubles }\end{array}$ & 12 & 7 & 65 & 15 & 25 \\
\hline $\begin{array}{l}\text { Gross value, } \\
\text { thousands of } \\
\text { rubles }\end{array}$ & 408 & 182 & 91 & 468 & 717.5 \\
\hline $\begin{array}{l}\text { Net income, } \\
\text { thousands of } \\
\text { rubles }\end{array}$ & 322.6 & 146.6 & 58.8 & 392.9 & 646.1 \\
\hline $\begin{array}{l}\text { Profitability } \\
\text { level, } \%\end{array}$ & 378 & 414 & 183 & 523 & 905 \\
\hline
\end{tabular}

If producing and adjustment of product processing, making juice and puree with a sign of its environmental friendliness profitability - profitability can raise on up to $1000 \%$.

\section{Conclusions}

1. Soil and climatic conditions of the mountain zone are characterized by favorable indicators for the cultivation of potatoes for the production of early-ripening environmentally friendly food potatoes.

2. The technology of organic farming in mountainous areas of the KBR with use of local varieties of early potatoes and using a special crop rotation with a complete rejection of plant protection means and mineral fertilizers allows to get a crop of potato tubers at 25 $\mathrm{t} / \mathrm{ha}$, while in intensive technology of $31.2 \mathrm{t} / \mathrm{ha}$.

3. According to the results of the study, it can be argued that the cultivation of early potatoes in compliance with organic farming conditions in the mountainous zone of the KBR is highly profitable production not only because of the yield obtained, but also because the use of mineral fertilizers and chemical means of protection is reduced to zero.

4. Production of vegetables in compliance with environmental standards of organic farming has high economic performance. At production and adjustment processing of the grown product, producing juice and puree and receiving the review of organic production profitability of production can raise on up to $1000 \%$.

5. Organic agriculture of production of vegetables and potatoes in the KabardinoBalkarian Republic is a full-cycle industry, which includes the creation and introduction of highly productive varieties of culture, reproduced seed production in a favorable natural and climatic background and the production of food potatoes in the conditions of 
mountainous zone. Sustainability and efficiency of organic vegetable production development is possible due to in-depth specialization in the integrated implementation of production, natural resources, investment potentials.

6. The conditions of the mountain zone above 1500 meters above the sea level are ideal for conducting environmentally friendly organic farming and growing all the tested varieties of domestic selection.

\section{References}

1. A.Yu. Kishev, I.M. Khanieva, T.B. Zherukov, Z.-G.S. Shibzukhov, Agrarnaya Rossia, 1, 19 (2019)

2. Yu.M. Shogenov, Z.-G.S. Shibzukhov, S.S.B Elmesov, T.S. Vindugov, Scientific and practical ways to improve environmental sustainability and socio-economic support of agricultural production, Proceedings of the international scientific and practical conference dedicated to the year of ecology in Russia, 344 (2017)

3. A.M. Elmesov, Z.-G.S. Shibzukhov, Modern ecological state of the natural environment and scientific and practical aspects of rational nature management, II international scientific and practical Internet conference, 822 (2017)

4. A. Ya. Tamakhina, A.A. Gadieva, R.A. Tiev, Z.-G.S. Shibzukhov, Z.L. Kantsalieva, Advances in Engineering Research, 946 (2018)

5. H.M. Nazranov, L.Z. Cambieva, Innovative technologies of national plant breeding and seed production, Collection of theses proceedings on materials of II scientificpractical conference of young scientists of the All-Russian forum on breeding and seed production, 191 (2018)

6. A.Yu. Kishev, I.M. Khanieva, N.I. Mamsirov, K.Z. Berbekov, Science, education and innovation for agriculture: Condition, problems and prospects, Materials of the $\mathrm{V}$ International scientific and practical conference dedicated to the 25 th anniversary of the Maikop state technological University, 61 (2018)

7. K.B. Mamaev, I.M. Khanieva, M.M. Kardanova, Promising innovative projects of young scientists, Materials of the VII All-Russian conference of students, postgraduates and young scientists, 115 (2017)

8. S.A. Bekuzarova, I.M. Khanieva, Innovative technologies of production of grain, legumes, technical and fodder crops, Jubilee collection of scientific papers, 285 (2016)

9. K.G. Magomedov, I.M. Khanieva, M.H. Shidukova, Areas of scientific thought 2014, 2015 , Materials of the XI International scientific and practical conference, 76 (2015) 